\title{
The Study on the Construction of Groups of Party and League of Students in Colleges and Universities
}

\author{
Hui-Hua ZHANG \\ College of Law, South China University of Technology, Higher Education Mega Center, Guangzhou \\ City, Guangdong Province, P.R.China, 510006 \\ hhzhang1@scut.edu.cn, 553662117@qq.com
}

Keywords: Colleges and universities, Construction of groups of party and league, Present situation, Solutions.

\begin{abstract}
Groups of Party and League of college students are the traditional carriers of ideological and political education in universities. And the construction of groups of Party and League of college students has always been the key work in Universities. With the reform of Higher Education becoming deeper ceaselessly, the construction of groups of Party and League of college students is facing many new problems and requirements. In order to adapt to the new situation and to do a better job in the work of ideological and political in universities, this paper is about to study and analyze the present situation, problems and solutions of the construction of groups of Party and League of college students.
\end{abstract}

\section{The outline of Groups of Party and League of colleges and universities}

\section{The traditional carriers of ideological and political education in colleges and universities}

Former President $\mathrm{Hu}$ Jintao once said that a country with far sight should attach much attention to the young people, while a political party should view the young people as an important force to accelerate history development and social advancement. Our country is such country and our political part[1]y is such party[1].

As the young people of the country, the growth of students in colleges and universities is related to the future of the country. To put ideological and political education school education in the first place of school education is the essential requirement of socialist education and the decision of our party's education policy [2].

Groups of Party and League of college students which play an important role in every historical stage are carrier of ideological and political education in colleges and universities. Now under the new historical conditions, we need to aware well that Groups of Party and League of college students are responsible to ideological and political education of students in colleges and universities from height view to enforce the construction of the party's ruling ability. At the same time, we need to attach much importance to the construction of the Groups of Party and League of college students in the urgent requirement of college and university students' education.

\section{The analysis of the current groups of Party and League of college students}

Groups of Party and League of college students mainly includes students party organizations, students league organizations, class committee and league branch (hereinafter referred to as the class union) and student union. All the above are the traditional carrier of ideological and political education in the colleges and universities which play an important role respectively.

The student party organization. The student party organization is the sail of faith of the students which is prominent in its advanced characteristics. Therefore thousands students desire to join such organization by improving themselves every year. Previously, the department of education released the results of university students' ideological and political condition of rolling survey in 2011, and the result shows that eighty percent of college students have the desire to be a member of the communist party of China [3].According to the statistics, there are 1.236 million students to become party members in 2010 , accounting for $40.2 \%$ of total national development party members. 
To December 31, 2010, there are 2.512 million college students to become party members [4].

The construction of the party organizations is an important part of the construction work of the party. "The party's construction in college and university is the requirement to ensure some successors of the party cause and adhere to the direction of building school. Besides, it is the fundamental guarantee to achieve the goal to cultivate students and gain healthy development of various undertakings. We should always understand the importance to construct the groups of college party in order to ensure the development of the party's cause, at the same time, we need to put the construction of the students' party organization in the first place to develop the work of ideological education." [5]

Students' league organizations. Students' league organizations are a song of students' youth which is prominent in its universality. That is to say, most college students are league members. According to the statistics, there are 75.439 million league members while college students league members occupies 15.7 percent with the total number 11.864 million by the end of 2007. [6]

The students union. The students union is their own organization which is prominent in its autonomy. The first students union was found on December 23, 1919 by Tsinghua University in the time of May 4th movement with the slogan patriotism, democracy and science. Under this circumstance, the origin of the students union decides its feature of autonomy and democracy.

League branch and class committee. League branch and class committee is prominent in its flexibility. Because it is the basic unit of the league organization work and activities, and it is the root and the first work for league ideological education. The foundation of the construction task of the league branch is to achieve the goal to develop talent people and unite all the students of the class to strive to build a unity friendly, healthy and vibrant class. Class committee is a students' organization which is set up by the students themselves to govern them. The function of class committee is to carry out resolutions and decisions of the school and the faculty and unite all the class to educate, govern, serve and constraint themselves in the guide of the upper organization.

\section{Problems of the construction of groups of Party and League at present}

\section{Putting forward this problem}

On October 4, 2014, the Yangcheng evening news published an article with the title "the claim for the youth league and students union in colleges and universities to be 'dirty place'__ associate professor of National People University blasting students union provoked controversy" [7]. And it became a heated debate.

This report is original from an article in a blog with the title "students union —- the darkest corner of college and university" [8].This blog claims that the youth league and students union in colleges and universities is the "dirty place", and points a series of problems and bad phenomena as follows. Firstly, students union forming by the students is governed by students themselves, so they just perform the decision of the youth committee. Secondly, teachers at class earnestly encourage students to cultivate independent personality and free spirit. Once they spare too much time to take part in the activities that they will waste time to study. Thirdly, the choice of the league committee and students union members is not in the procedure of open, transparent, fair and democratic process, but in the procedure of internal decision. Fourthly, the youth committee and students union organize so large-scale activities that it will affect their study. Fifthly, Student cadres are in privilege of the students. Like some school awards is set by the youth league and chosen by the organization. Under this condition, most awards are given to student cadres, in fact they aware the prize to themselves. They can add some scores when they apply for the master degree. At the same time, schoolmaster Yang Yuliang of Fudan University once criticized "the strange phenomena of student official circles" and criticized some students to regard utility too much at the opening ceremony.

Aiming at this phenomenon, microblog association of Tsinghua University launched a vote "Are you satisfied with your school's youth league and students union?" Some participating in this vote showed they didn't satisfy with their school's youth league and students union. Although the survey still has some questions, for example investigation random samples existing questions. But there is 
no doubt that it becomes imminent to know how to construct groups of Party and League under the network environment.

\section{The summary of the problems and reasons}

The above network events reflect some problems of the construction of party and league under the new circumstance that provokes some serious and careful thinking. There are the summary of the problems and reasons as follows.

The lack of the goal and function of groups of Party and League in colleges and universities. Groups of Party and League are a traditional carrier of ideological and political education in college and university. The fundamental goal of groups of Party and League is to view the students as most important, to improve their ideological and political quality and cultural quality relying on the construction of groups of Party and League. The function of groups of Party and League is different. Some problems obviously to occur mainly depend on following factors. In order to pursue honor, that they hold some unpopular activities with the students out of direction. Besides some student cadres in order to be responsible for organizing activities that they do not have class, even some students are asked to take part in an activity to create an atmosphere for the activity. All these will affect their study. These are the reasons why some teachers reflect that students' organizations offset their education effort. Deviation the direction based on students, to construct satisfied groups of Party and League will not succeed.

Some student cadres "utilitarian". "There exists a such management idea at present in colleges and universities that in order to create more space for students, provide more opportunities to show and practice themselves and to arouse the enthusiasm of students, they lessen the selection standard to chose student cadres. Consequently, it leads to some problems, such as the organization is too big, has too many members and there occurs some problems to cultivate and supervise student cadres" . Some student cadres' quality is not good; some students mistake their responsibility as power and some bad influence from the society imposed to student cadres. It forms a field of "bureaucratic" and "utilitarian", for example platter the teacher and talk with the classmates in a bureaucratic manner, and use activity funds to eat.

The lack of good supervision and evaluation mechanism in the construction of groups of Party and League in colleges and universities. There are still some problems in the aspect of the development of student party members, the selection of students union and youth league cadres, the budget details of some activities, the interest distribution of scholarship and postgraduate recommendation. Given this, many people criticize the league committee and student union becomes a dirty place in colleges and universities. There are two factors as follows. The first is that we have not done enough for ideological and political education and students' qualities. The second is that it is lack of good supervision and evaluation mechanism in the construction of groups of Party and League in colleges and universities. The construction of supervision mechanism of the groups of Party and League becomes apparently significant in the Internet context. Only let most college students participate, set up good supervision mechanism can light up groups of Party and League and satisfy the students.

\section{The solutions to the problems of groups of party and league}

Base on the party construction to contribute to league construction, and create satisfied groups of party and league

Implement the model of the party construction to contribute to league construction. In theory and practice, the most successful achievements and experience is to implement the model based on party construction to contribute to league construction. "To construct league based on party construction is the requirement since the work conference to construct league based on party construction hold by the central department in 2000. Party organizations at all levels from the aspects of thought, organization, style and system to explore effective methods and some have come into effect." .Tsinghua university and other colleges and universities promote the mechanism of 
based on the party construction to develop league each other. In the operation mode of the youth league organizations at all levels, the mechanism of based on the party construction to develop league has its theory and successful practice experience. Therefore, we need to adhere to this mechanism in the construction of groups of Party and League.

Base on students and meet the demand of youth. "To meet the needs of group of Party and League is the demand of era. The first basic category of Marxism sociology on social operation is the need. Efficient operation of groups of party and league is the same as the social operation mechanism, which stems from the needs of youth. So it is necessary to understand the needs of youth and satisfy the youth in the construction to groups of party and league". We need to regard "to base on the student and meet the demand of youth" as the starting point of work in the construction of university party and league organization. Besides we need to hold some recreational activities to serve for the students in the work of ideological and political education. In a word, taking their needs into consideration and catering their needs will let more young people satisfy the construction of groups of Party and League.

Combine theory with practice and strengthen incorruptible education of student cadres in colleges and universities

In view of bad social influence on the college student cadres at present, there are some necessities to strengthen incorruptible education of student cadres in colleges and universities. All the above, to strengthen incorruptible education of student cadres in colleges and universities, we need to combine theory with practice .

Take advantage of the organization and conduct ideological education activities. We can gather students and student cadres to learn relevant documents and conference spirit and explain and discuss incorruptible education related with their own. Thus let the students can understand the goal, its significance, its task, its guiding ideology, its main contents and basic requirements of incorruptible education of student cadres and party in a systematic way. At the same time let student cadres understand bear is the responsibility for student cadres rather than power.

Rely on campus cultural activities and strengthen the integrity infiltration education. Combine incorruptible education of student cadres with the construction of campus culture to cultivate their interests and influence them by a variety of forms and carriers. During the activities of debate, science and art festival and other cultural activities, we can arrange some debates related to incorruptible education, some performance cultural programs and some films such as "good children of people". Make full use of campus cultural activities to contribute to incorruptible education.

Combine with social practice and strengthen the integrity education effect. We should adhere to theory with practice in incorruptible education for student cadres. Practice is an important part of education and we ask students to go out to practice in some basic places.

Take advantage of microblog information platform to perfect the supervision and evaluation mechanism of groups of Party and League

Bear a new meaning for microblog to the construction of groups of Party and League. In the information age, the Internet has increasingly changed the growth environment and the life style of college students. Especially as the occurrence of microblog platform with its open, interactive and convenient services for individuals or organizations to show oneself and itself, it becomes popular with college students. In order to further explore new media to communicate with young students, strengthen and innovate the construction of college communist youth league organization and grass-roots work and promote communist youth league organization in colleges and universities to realize network transformation. The administration has issued a note "league organizations in colleges and universities set up microblog system". We can make use of micro-topic, micro-interview, micro investigation to have a knowledge of true thoughts of college students for educators by microblog platform. Then put some ideological education information to direct the students in the Internet. From this perspective, they can establish good ideological concept and good faith. By this way, it can improve the effect and pertinence for college students of teir ideological 
and political education. Taking advantage of this platform, we can chombine main stream thoughts and right public opinions well with microblog. Mutual penetration and integration step by step each other, it has a time meaning to strengthen the construction of the groups of Party and League and educate college students for their thoughts.

Depend on microblog platform to perfect the supervision and evaluation mechanism of groups of Party and League. "Student unions and youth league becomes the dirty place in school", "Student cadres become bureaucratic" and "As the vote by microblog shows that 80 percent people is not satisfied with school youth league committee and student unions". It is widely and fast spread by microblog. All these reflect the problems of groups of Party and League in colleges and universities. At the same time, we can seize the chance of microblog to strengthen the construction of groups of Party and League. Establish supervision and evaluation mechanism to let more students to participate in the construction of groups of Party and League. At the request of the central file, youth league organizations at all levels of colleges and universities across the country are actively cooperate with their quest to establish microblog. Making full use of microblog to improve the construction of youth league organization is consistent with the situation, whereas the model is in the exploration. Except youth league organization, student party organization, student union and class youth league organization, they also try to set up microblog to show them and accept supervision and evaluation. Through the microblog platform, groups of Party and League can solicit opinions and evaluation from students to meet people's demands before they hold some activities. In the term of choosing student cadres, evaluation scholarship, postgraduate recommendation, the funds, we had better consider students' opinions and accept their supervision though the microblog platform. Thus it can make groups of Party and League with justice and transparency.

\section{References}

[1] Commentator of People's Daily Newspaper, Won the youth, is to win the future and

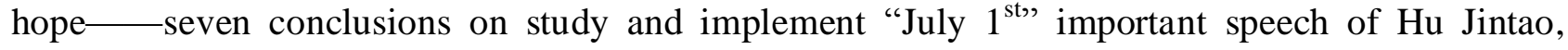
People's Daily Newspaper, vol.1, 2011.

[2] Meng Tinghua, on how to innovate university student ideological and political work on the new context, Journal of Hunan Institute of Science and Technology, vol.4, pp.55-56, 2005.

[3] China news, Survey said nearly eighty percent of college students have a desire to join in the party, China News, 2011.

[4] Yang Chenguang, There are2.51million students of colleges party members in China, China Education Newspaper, vol.1, 2011.

[5] Zhao E'na, Tsinghua University students carry out students' party construction with its own characteristic, Party construction web, 2010.

[6] The communist youth league of the central, the working notification of the development youth league in 2007 issued by the center office of the communist youth league, Central Regulations, 2008.

[7] Zheng Xusen, Li Yating, the claim for the youth league and students union in colleges and universities to be 'dirty place'__ associate professor of National People University blasting students union provoked controversy, Yangcheng Evening Newspaper, vol.3,2011. 